\title{
EARLY ACTIONS OF CADMIUM IN THE RAT AND DOMESTIC FOWL TESTIS
}

\author{
IV. AUTORADIOGRAPHIG LOGATION OF ${ }^{115 \mathrm{~m}}$ GADMIUM* $^{*}$
}

\author{
A. D. JOHNSON AND M. B. SIGMAN \\ Department of Animal Science, \\ The University of Georgia, Athens, Georgia, U.S.A.
}

(Received 17th August 1970)

The location of cadmium ( $\mathrm{Cd}$ ) has been demonstrated in the testis of the mouse 16 days after injection (Berlin \& Ullberg, 1963) and in the testis of the rabbit and guinea-pig $1 \frac{1}{2} \mathrm{hr}$ after injection (Skold, 1961). The arrival of ${ }^{109} \mathrm{Gd}$ in the testis of the rat and the domestic fowl as early as $2 \frac{1}{2}$ min after injection has been found (Johnson \& Miller, 1970).

The damaging effect of $\mathrm{Gd}$ in the mammalian testis and the absence of such an effect in the avian testis has been recently reviewed by Gunn \& Gould (1970). This differential effect raises the question of whether location of Cd is different in the testes of these two groups of animals. In attempting to answer this question, the location of ${ }^{115 \mathrm{~m}} \mathrm{Gd}$ in the testis was determined autoradiographically in representatives of these two groups of animals.

Six mature male rats of the Wistar strain and six mature male Bantam domestic fowl were used as experimental animals. The rats weighed from 350 to $761 \mathrm{~g}$ and the domestic fowl from 776 to $1858 \mathrm{~g}$.

The ${ }^{115 \mathrm{~m}} \mathrm{GdCl}_{2}$ with a specific activity of $380 \mu \mathrm{c} / \mathrm{mg}$ (New England Nuclear Corp., Boston, Mass.) was obtained in a $2 \cdot 6-\mathrm{ml}$ stock solution of $3 \mathrm{~N}-\mathrm{HCl}$. This was diluted to $10 \mathrm{ml}$ with $7.4 \mathrm{ml}$ of buffer consisting of distilled water and $1.918 \mathrm{~g}$ of sodium acetate (final $\mathrm{pH}=5$ ). The diluted solution containing 200 $\mu \mathrm{c} / \mathrm{ml}$ was injected into both species subcutaneously (s.c.) in the interscapular region at the level of $0.19 \mu \mathrm{c}$ or $0.9 \mu \mathrm{l} / \mathrm{g}$ body weight.

Both species were divided into three groups, anaesthetized with sodium pentobarbital, and killed at $2 \frac{1}{2}, 10$ or $40 \mathrm{~min}$ after injection of ${ }^{115 \mathrm{~m}} \mathrm{Cd}$. Both left and right testes were removed for autoradiographic studies and were immediately placed in Bouin's solution which contained $0.68 \mathrm{mg} \mathrm{CdCl}_{2} / 100$ $\mathrm{ml}$ to prevent migration of ${ }^{115} \mathrm{Cd}$ from the testis.

The testes were embedded in paraffin wax, sliced at $5 \mu$, and stained with Harris haematoyxlin-eosin. Except for those which served as unexposed controls, the sections were coated with NTB2 Kodak emulsion using the autoradiography technique of Kopriwa \& Leblond (1962).

On the 26th day (found best in pilot studies and continual testing) after

* University of Georgia, College of Agriculture Experiment Stations Journal Series Paper No. 675, College Station, Athens. 
emulsion coating, the slides were processed in a dark room with Kodak Dektol Developer for $5 \mathrm{~min}$, distilled $\mathrm{H}_{2} \mathrm{O}$ for $10 \mathrm{sec}, \mathrm{F} 5 \mathrm{Kodak}$ Acid Fixer for $5 \mathrm{~min}$, and distilled $\mathrm{H}_{2} \mathrm{O}$ for $5 \mathrm{~min}$. The solutions were held at approximately $18^{\circ} \mathrm{C}$ during the developing process.

Slides were examined closely with a light microscope to determine the location of the ${ }^{115 \mathrm{~m}} \mathrm{Cd}$ in the testis as evidenced by darkened areas resulting from exposure of the emulsion to the radiation. Representative micrographs of both exposed and unexposed sections were taken with identical lighting and magnification.

In the testes of the rats at $2 \frac{1}{2} \mathrm{~min}$ after injection, the vessels contained blood which was heavily laden with ${ }^{115 \mathrm{~m}} \mathrm{Gd}$ (Pl. 1, Fig. 1). At $10 \mathrm{~min}$ after injection, the ${ }^{115 \mathrm{~m}} \mathrm{Gd}$ was considerably less concentrated in the vessels (Pl. 1, Fig. 2) and in some areas appeared to be dispersing from the vessels into the intertubular areas immediately around the vessels.

At $40 \mathrm{~min}$ after injection, many blood vessels appeared to be free of 'labelling' and the ${ }^{115 \mathrm{~m}} \mathrm{Gd}$ appeared to be fairly evenly dispersed throughout the intertubular areas (Pl. 1, Fig. 3).

In the testes of the domestic fowl at $2 \frac{1}{2} \mathrm{~min}$ (Pl. 1, Fig. 4), the labelled Cd, as indicated by the darkened areas, was concentrated in the blood vessels. At $10 \mathrm{~min}$ (Pl. 1, Fig. 5), there was a further dispersal of the ${ }^{115 \mathrm{~m}} \mathrm{Cd}$ into some of the intertubular areas around the vessels. By $40 \mathrm{~min}$ (Pl. 1, Fig. 6), there was further dispersal of the ${ }^{115 \mathrm{~m}} \mathrm{Cd}$ throughout this area. During this period, it appeared that the ${ }^{115 \mathrm{~m}} \mathrm{Cd}$ was closely associated with the basement membrane as well as the limited amount of interstitial tissue found in the domestic fowl.

There was no consistent pattern of oedema or change in vascular structure during the period studied. Such changes might not be expected since the dose

\section{EXPLANATION OF PLATE 1}

Frgs. 1 to 3. Photomicrographs of the rat testis at various times after injection of $115 \mathrm{~m} C d$. Tissues were fixed in Bouin's, stained with Harris haematoxylin-eosin and exposed to radiosensitive emulsion for 26 days $(\times 84)$.

Fig. 1. Section of the testis of the rat $2 \frac{1}{2}$ min after injection of $0.19 \mu \mathrm{c}^{115 \mathrm{~m}} \mathrm{Cd} / \mathrm{g}$. Note the heavily darkened areas in the vessels throughout the area which are indicative of heavy concentration of the radioactive material.

Frg. 2. Photomicrograph of the rat testis $10 \mathrm{~min}$ after ${ }^{115 \mathrm{~m}} \mathrm{Cd}$ injection. The ${ }^{115 \mathrm{~m}} \mathrm{Cd}$ appears less concentrated in the blood vessels and a few small areas adjacent to the vessels are darkened.

Fig. 3. Section of the rat testis $40 \mathrm{~min}$ after injection of $115 \mathrm{~m} \mathrm{Cd}$. Some vessels appear devoid of the ${ }^{115 \mathrm{~m}} \mathrm{Cd}$ while others still contain the isotope. The areas surrounding the tubules are darkened, indicating a dispersion of the $\mathrm{Cd}$ into these areas and away from the vessels.

Figs. 4 to 6 . Sections of the testes of the domestic fowl at various times after s.c. injection of ${ }^{115 \mathrm{~m}} \mathrm{Cd}$. Sections prepared as in Figs. 1 to $3(\times 84)$.

Fig. 4. Section of the domestic fowl testis, including a portion of the tunica albuginea, at $2 \frac{1}{2} \mathrm{~min}$ after injection. The ${ }^{115 \mathrm{~m}} \mathrm{Cd}$ is concentrated in the vascular system. There was also some ${ }^{115 \mathrm{~m}} \mathrm{Cd}$ in the tunica albuginea.

FIG. 5. View of the domestic fowl testis $10 \mathrm{~min}$ after injection. The darkened area, indicating the presence of radioactive material, was still primarily in the blood vessels but was less concentrated than at $2 \frac{1}{2} \mathrm{~min}$ and appeared to be moving into the immediately adjacent areas.

Fig. 6. A portion of the testis of the domestic fowl at $40 \mathrm{~min}$ after injection. The ${ }^{115 \mathrm{~m}} \mathrm{Cd}$ appears to be dispersed throughout the intertubular area. 
PI.ATE 1
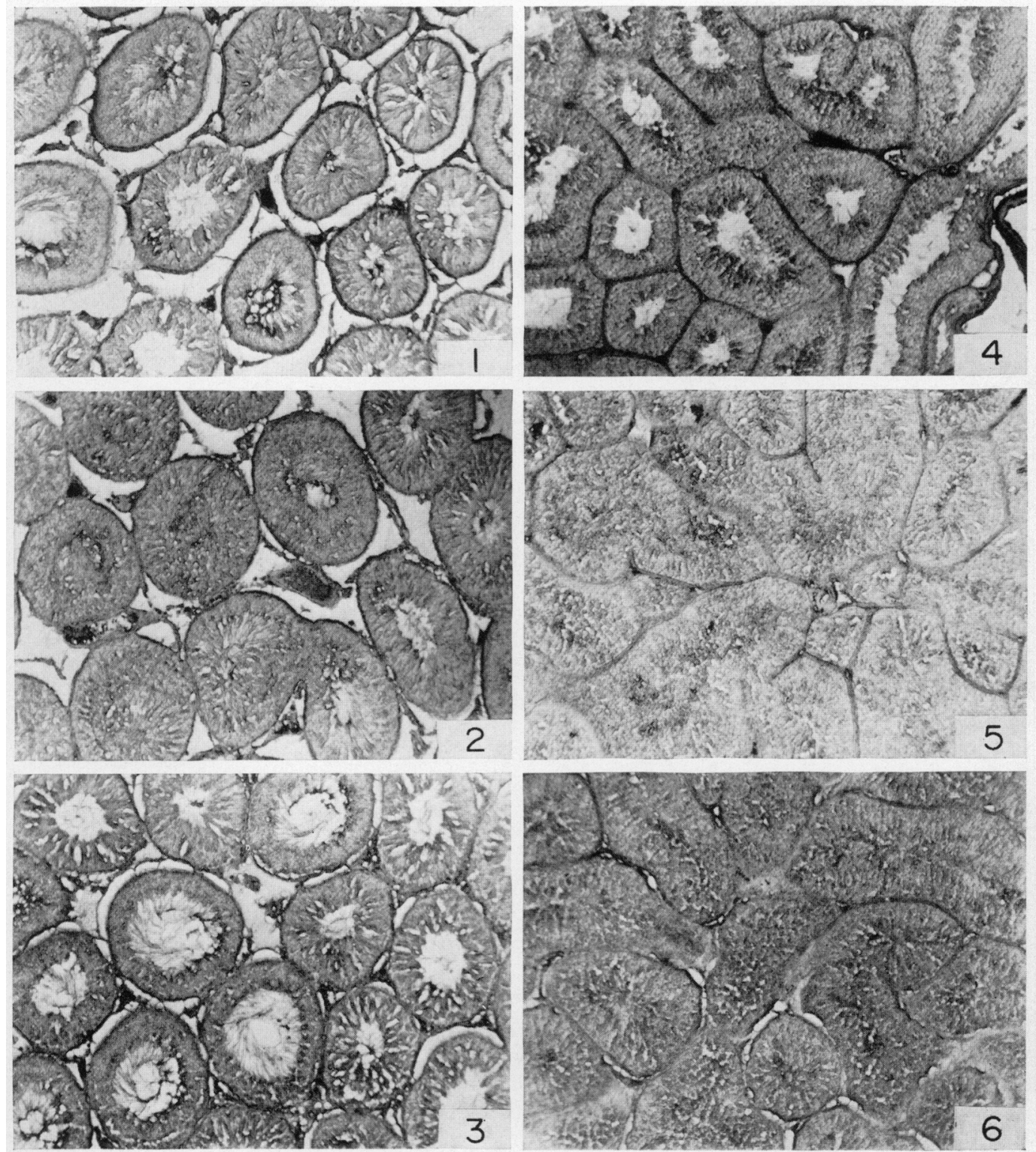

(lacing p. 116) 
used, $0.001 \mathrm{mmol} / \mathrm{kg}$, was below the minimal damaging dose for the rat, 0.01 $\mathrm{mmol} / \mathrm{kg}$ of body weight (Gunn \& Gould, 1970).

Gadmium has been shown to reach a peak level in the blood of the rat and the domestic fowl at 5 and $20 \mathrm{~min}$, respectively, following intraperitoneal (i.p.) injections and in the rat at 10 min following s.c. injection (Johnson \& Miller, 1970). Following these peaks, the level of ${ }^{109} \mathrm{Cd}$ in the blood decreased very rapidly. The changes in the amount of autoradiographically detectable blood Gd appear to agree well with these previously reported changes.

By 10 , and certainly by $40 \mathrm{~min}$, the Gd appears to leave the vasculature and become located in the intertubular areas in both species. The location of $\mathrm{Cd}$ in the testes of various mammals at $1 \frac{1}{2} \mathrm{hr}$ (Skold, 1961) and 16 days (Berlin \& Ullberg, 1963) suggests that the Cd remains in the intertubular areas for prolonged periods of time.

Levels of Gd tend to decrease in the testis soon after reaching peak levels. Fairly consistent levels of $\mathrm{Gd}$ in the testicular tissue are probably reached within the first few minutes and the decreasing trends which occur after $40 \mathrm{~min}$ (Johnson \& Miller, 1970), $4 \mathrm{hr}$ (Gunn, Gould \& Anderson, 1968a) or 1 day (Gunn, Gould \& Anderson, 1968b) may be due initially to a reduction in the amount of $\mathrm{Cd}$ in the blood and later to removal from the vascular tissue and its surrounding areas. In the mouse, it appears that this decrease in testis Gd level is very gradual from 1 day to at least 6 weeks (Gunn et al., 1968b).

The subcellular location of Gd at these initial periods after injection (Johnson, Sigman \& Miller, 1970) as related to the present work, suggests that at $2 \frac{1}{2} \mathrm{~min}$ the Gd would be associated with the cells of the blood. As time elapses after injection, Gd passes to the cells of the vascular endothelium, and then to those of the intertubular areas.

In this study, no differences were found in the location of $\mathrm{Cd}$ in the testes or the rat and the domestic fowl. The rate of arrival at various sites as well as the concentration in those areas appeared to be strikingly similar in both species. This still leaves unanswered the question of why a differential response to Gd exists between the mammalian and avian testes. It is possible that there is a differential response of certain key enzyme systems to Gd in the testes of these two groups of animals or a difference in tolerance to early changes brought about by Gd.

\section{REFERENGES}

Berlin, M. \& Ullberg, S. (1963) The fate of ${ }^{109} \mathrm{Cd}$ in the mouse. Archs envir. Hlth, 7, 686.

Gunn, S. A. \& Gould, T. C. (1970) Cadmium and other mineral elements. In: The Testis. 3. Influencing Factors. Eds. A. D. Johnson, W. R. Gomes and N. L. VanDemark. Academic Press, New York.

Gunn, S. A., Gould, T. C. \& ANderson, W. A. D. (1968a) Mechanisms of zinc, cysteine and selenium protection against cadmium-induced vascular injury to mouse testis. $\mathcal{7}$. Reprod. Fert. 15, 65.

Gunn, S. A., Gould, T. G. \& Anderson, W. A. D. (1968b) Failure of ${ }^{109}$ Cd to traverse spermatogenic pathway. 7. Reprod. Fert. 16, 125.

Johnson, A. D. \& Mrller, W. J. (1970) Early actions of cadmium in the rat and domestic fowl testis. II. Distribution of injected ${ }^{109}$ cadmium. F. Reprod. Fert. 21, 395.

Johnson, A. D., Sigman, M. B. \& Mirler, W. J. (1970) Early actions of cadmium in the rat and domestic fowl testis. III. Subcellular location of injected ${ }^{109}$ cadmium. F. Reprod. Fert. 23, 201.

Kopriwa, B. M. \& Leblond, C. P. (1962) Improvements in the coating techniques of radioautography. F. Histochem. Cytochem. 10, 269.

Skold, G. (1961) Effects of cadmium poisoning on testes. Acta path. microbiol. scand. 53, 440. 